Obtained in Celebes by Dr. Meyer, and represented by a single example in such bad order that I am unable to describe it more minutely. Many of the abdominal feathers seem to be pure white, and the chin, throat, and ear-coverts to be pale fulvous.

\title{
XLIII.-On a new Species of Thrush pertaining to the Genus
} Oreocincla. By JoHN Gould, F.R.S. \&c.

\section{Oreocincla iodura, Gould.}

Crown of the head, back, and wing-coverts orange-brown, becoming of a paler and brighter tint on the rump and upper tail-coverts, each feather being margined with blackish brown; four middle tail-feathers of the same colour as the rump; the three next on each side dark brown, very slightly tipped with buffy white; the external feather light brown, with at least an inch of buffy white on the tip of the inner web; circle round the eye, lores, and a patch on the centre of the ear-coverts buffy white; throat and all the under surface white, each feather tipped with a lunate mark of black, which is broadest and blackest on the chest and flanks; across the breast a wash of buff; axillaries white at the base, black on their apical half; the last row of the lesser wing-coverts tipped with yellowish white; greater coverts orange-brown, tipped with yellowish; spurious wing and primaries dark brown, margined externally with orange-brown; secondaries dark brown on their internal and orange-brown on their external webs; vent and under tail-coverts buffy white, without lunations.

Total length $9 \frac{1}{4}$ inches; bill $1 \frac{1}{8}$, wing $5 \frac{1}{8}$, tail $3 \frac{3}{4}$, tarsi $1 \frac{1}{8}$.

Habitat. Queensland and Northern Australia.

Remark. After carefully comparing this bird with examples of the genus from every other part of Australia, from Java, the Philippines, China, and India, I cannot come to any other conclusion than that it is distinct from the whole of them. In comparison with the Australian members of the genus, it is a smaller, much neater, and more compact bird, and has the rump and upper tail-coverts orange-brown instead of olivebrown; the bill also is smaller, narrower, and more delicately formed than that of the Tasmanian and New-South-Wales species. 


\section{$2 \mathrm{BHL}$ Biodiversity Heritage Library}

Gould, John. 1872. "XLIII.-On a new species of Thrush pertaining to the genus Oreocincla." The Annals and magazine of natural history; zoology, botany, and geology 9, 401-401. https://doi.org/10.1080/00222937208696606.

View This Item Online: https://www.biodiversitylibrary.org/item/54555

DOI: https://doi.org/10.1080/00222937208696606

Permalink: https://www.biodiversitylibrary.org/partpdf/53810

\section{Holding Institution}

Smithsonian Libraries

\section{Sponsored by}

Smithsonian

\section{Copyright \& Reuse}

Copyright Status: Public domain. The BHL considers that this work is no longer under copyright protection.

This document was created from content at the Biodiversity Heritage Library, the world's largest open access digital library for biodiversity literature and archives. Visit BHL at https://www.biodiversitylibrary.org. 